\title{
Prevalence of Agglutinating Antibodies to Toxoplasma gondii and Sarcocystis neurona in Beavers (Castor canadensis) From Massachusetts
}

Author(s): Carly N. Jordan, Taranjit Kaur, Kiana Koenen, Stephen DeStefano, Anne M. Zajac , and David S. Lindsay

Source: Journal of Parasitology, 91(5):1228-1229. 2005.

Published By: American Society of Parasitologists

DOI: http://dx.doi.org/10.1645/GE-543R.1

URL: http://www.bioone.org/doi/full/10.1645/GE-543R.1

BioOne (www.bioone.org) is a nonprofit, online aggregation of core research in the biological, ecological, and environmental sciences. BioOne provides a sustainable online platform for over 170 journals and books published by nonprofit societies, associations, museums, institutions, and presses.

Your use of this PDF, the BioOne Web site, and all posted and associated content indicates your acceptance of BioOne's Terms of Use, available at www.bioone.org/page/terms of use.

Usage of BioOne content is strictly limited to personal, educational, and non-commercial use. Commercial inquiries or rights and permissions requests should be directed to the individual publisher as copyright holder. 
Kraus, S. D., K. E. Moore, C. E. Price, M. J. Crone, W. A. Watkins, H. E. Winn, AND J. H. PrescotT. 1986. The use of photographs to identify individual North Atlantic right whales (Eubalaena glacialis). Reports of the International Whaling Commission, Special Issue 10: $145-151$.

MeAsures, L. M., AND M. Olson. 1999. Giardiasis in pinnipeds from Eastern Canada. Journal of Wildlife Diseases 35: 779-782.

Monis, P. T., R. H. Andrews, G. Mayrhofer, and P. L. Ey. 2003. Genetic diversity within the morphological species Giardia intestinalis and its relationship to host origin. Infection, Genetics, and Evolution 3: 29-38.

Morgan, U. M. L. Xiao, B. D. Hill, P. O’Donoghue, J. Limor, A. Lal, AND R. C. Thompson. 2000. Detection of the Cryptosporidium parvum "human" genotype in a dugong (Dugong dugon). Journal of Parasitology 86: 1352-1354.

Morgan-Ryan, U. M., A. Fall, L. A. Ward, N. HijJawi, I. Sulaimann, R. Fayer, R. C. Thompson, M. Olson, A. Lal, and L. Xiao. 2002. Cryptosporidium hominis n. sp. (Apicomplexa: Cryptosporidiidae) from Homo sapiens. Journal of Eukaryotic Microbiology 49: 43340.

Olson, M. E., P. D. Roach, M. Stabler, and W. Chan. 1997. Giardiasis in ringed seals from the western arctic. Journal of Wildlife Diseases 33: $646-648$.
REeves, R. R. 1998. Distribution, abundance and biology of ringed seals (Phoca hispida): An overview. North Atlantic Marine Mammal Commission Scientific Publication 1: 46-62.

Rickard, L. G., C. Siefker, C. R. Boyle, and E. J. Gentz. 1999. The prevalence of Cryptosporidium and Giardia spp. in fecal samples from free-ranging white-tailed deer (Odocoileus virginianus) in the southeastern United States. Journal of Veterinary Diagnostic Investigation 11: $65-72$.

Rulofson, F. C., E. R. Atwill, and C. A. Holmberg. 2001. Fecal shedding of Giardia duodenalis, Cryptosporidium parvum, Salmonella organisms, and Escherichia coli $\mathrm{O} 157: \mathrm{H} 7$ from llamas in California. American Journal of Veterinary Research 62: 637-642.

Ryan, U. M., P. Monis, H. L. Enemark, I. Sulaiman, B. Samarasinghe, C. Read, R. Buddle, I. Robertson, L. Zhou, R. C. A. Thompson, AND L. XIAO. 2004. Cryptosporidium suis n. sp. (Apicomplexa: Crytposporidiidae) in pigs (Sus scrofa). Journal of Parasitology 90: 769-773.

Siefker, C., L. G. Rickard, G. T. Pharr, J. S. Simmons, and T. M. O'HARA. 2002. Molecular characterization of Cryptosporidium sp. isolated from northern Alaskan caribou (Rangifer tarandus). Journal of Parasitology 88: 213-216.

XiaO, L., R. FAYer, U. RyAn, AND S. J. Upton. 2004. Cryptosporidium taxonomy: Recent advances and implications for public health. Clinical Microbiology Reviews 17: 72-97.

\section{Prevalence of Agglutinating Antibodies to Toxoplasma gondii and Sarcocystis neurona in Beavers (Castor canadensis) From Massachusetts}

Carly N. Jordan, Taranjit Kaur, Kiana Koenen*, Stephen DeStefano*, Anne M. Zajac, and David S. Lindsay†, Department of Biomedical Sciences and Pathobiology, Virginia-Maryland Regional College of Veterinary Medicine, Virginia Tech, 1410 Prices Fork Road, Blacksburg, Virginia 24061-0342; *U.S. Geological Survey, Massachusetts Cooperative Fish and Wildlife Research Unit, University of Massachusetts, Amherst, Massachusetts 01355. †To whom correspondence should be addressed. e-mail: lindsayd@vt.edu

ABSTRACT: The present study examined the seroprevalence of Toxoplasma gondii and Sarcocystis neurona in a population of beavers (Castor canadensis) from Massachusetts. Sixty-two blood samples were collected during the field seasons over 3 consecutive years from different animals. Blood was collected onto filter paper and shipped to the Department of Biomedical Sciences, Virginia Tech, Blacksburg, Virginia, for parasite testing. The samples were tested at dilutions of 1:25, 1:50, and 1:100 against each parasite antigen by modified agglutination tests to determine whether antibodies to either parasite were present in the blood. Six of 62 samples $(10 \%)$ were positive for T. gondii, with 2 samples having titers of $1: 25$ and 4 having titers of 1:50. Four of 62 samples $(6 \%)$ were positive for $S$. neurona, with 2 samples having titers of 1:25 and 2 having titers of 1:50.

Toxoplasma gondii is an important protozoal pathogen of humans and other warm-blooded vertebrates. Humans become infected by ingesting meat containing tissue cysts or by ingesting oocysts in the environment. Domestic cats and other felines are the only known, definitive hosts for $T$. gondii. Cats can excrete millions of environmentally resistant oocysts in their feces. Sporulated $T$. gondii oocysts have been reported to be able to survive in the environment for $1.5 \mathrm{yr}$ by Frenkel et al. (1975) and for $4.5 \mathrm{yr}$ at $4 \mathrm{C}$ by Dubey (1998). The cat population in the United States was $\sim 57$ million in 1991 (Patronek, 1998). The prevalence of antibodies to T. gondii is $\sim 58 \%$ in free-roaming cats and $37 \%$ in pet cats (Dubey, 1994). Outbreaks of T. gondii resulting from contaminated water have been described (Dubey, 2004). The prevalence of $T$. gondii antibodies in beavers may reflect the environmental exposure to $T$. gondii in aquatic ecosystems.

Sarcocystis neurona is an obligate, heteroxenous parasite that has the opossum as its definitive host. Intermediate hosts are infected by ingestion of sporocysts passed in opossum feces. Sarcocystis neurona is important because it is the causative agent of equine protozoal mye- loencephalitis, a severe neurological disease that can occur when a horse accidentally ingests $S$. neurona sporocysts. Horses may become infected by drinking sporocyst-contaminated water.

Little is known about the prevalence of apicomplexan parasites in beavers. The present study was conducted to determine the seroprevalence of $T$. gondii and S. neurona in beavers from Massachusetts.

Beavers were live-trapped as part of a larger project on their demographics. Four study areas have been established across Massachusetts to represent a combination of different levels of development and different attitudes of residents regarding management of beavers (Deblinger et al., 1999). The northeastern area of Massachusetts represents heavy suburban development, and a majority of people there are opposed to recreational fur-trapping (based on how residents voted on a statewide trapping referendum). The central area represents light suburban development, and a slight majority of people there are in favor of recreational trapping. The southwestern area is rural, with a slight majority of people opposed to trapping, and the northwestern area is rural, with the majority of residents in favor of recreational trapping. Colonies were surveyed and beavers captured and marked at sites in the eastern, central, and western areas of the state. At least some of these localities are sites included in the state's long-term, beaver colony-monitoring program, which has been ongoing for the last 7-8 $\mathrm{yr}$.

Bobcats (Felis rufus) as well as feral and pet domestic cats were present in all study areas (K. Koenen and S. DeStefano, pers. obs.). One of 9 documented mortalities of beavers included predation by a bobcat of a kit during a year of low water levels in the western study area. Bobcats are capable of dealing with human influences, but they tend to avoid agricultural areas with extensive cleared lands that eliminate other vegetative cover types. Bobcats can be classified as being common in central and western Massachusetts, present in the northeast, and rare to absent in southeastern areas of the state (Massachusetts Division of Fisheries and Wildlife, unpubl.). 
Beavers were captured at multiple colonies within each of the 3 study areas. Box traps (Koenen et al., in press) and Bailey traps were used to capture beavers, and each animal was immobilized with an intramuscular injection of ketamine hydrochloride (10-13 mg/kg) and acepromazine maleate $(2.5 \mathrm{mg}$ ) (Lancia et al., 1978). Age and sex were determined for each animal, and individuals were marked with metal and plastic ear tags as well as a tail-mounted radio transmitter. Given the difficulty of venipuncture in beavers, an alternative method for collecting samples was employed. Drops of blood were blotted onto filter paper following a cutaneous tail stick using a hypodermic needle. This is a reliable method of collecting blood for use in toxoplasmosis testing, as described in congenitally infected infants (Hsu et al., 1992; Patel and Holliman, 1994; Paul et al., 2001). It also has been used in sheep (Uggla and Nilsson, 1987) and cats (Nogami et al., 1992). After marking, beavers were placed back into box traps in a shady, protected area near the water, and individuals were not released until they had recovered fully from the drugs. Recovery was judged on the basis of the beaver's alertness, mobility, and ability to hold up its head and to move within the box trap (Koenen et al., in press).

The filter-paper blood blots were kept on ice packs and mailed to the Center for Molecular Medicine and Infectious Diseases, Department of Biomedical Sciences and Pathobiology, Virginia-Maryland Regional College of Veterinary Medicine, Virginia Tech, for testing. Sections (1 $\mathrm{cm}^{2}$ ) containing the dried blood were cut from the filter-paper blots and submerged in $200 \mu \mathrm{l}$ of phosphate-buffered saline (PBS). The paper was soaked overnight at $4 \mathrm{C}$ to allow blood proteins to dissolve into the PBS. Then, the eluate was removed and placed into clean tubes for use in agglutination testing.

The modified direct agglutination test (MAT) was used to examine beaver eluates for agglutinating immunoglobulin $\mathrm{G}$ antibodies to $T$. gondii (Dubey and Desmonts, 1987) and S. neurona (Lindsay and Dubey, 2001). A dilution of 1:25 was used to screen sera. Thirty-one serum samples were tested from beavers in 2002, 17 in 2003, and 14 in 2004. Positive beaver sera were examined further at dilutions of 1:50 and 1:100.

Positive T. gondii MAT results were found in 6 of 62 beavers (10\%) from 2002. Four samples were positive at 1:50, and 2 samples were positive only at $1: 25$. Four of 62 beavers (6\%) from 2002 were positive for $S$. neurona by MAT. Two were positive at 1:50, and 2 were positive only at 1:25. No samples from 2003 or 2004 were positive for $T$. gondii or S. neurona.

Toxoplasma gondii has been isolated from a beaver in Kansas (Smith and Frenkel, 1995). The prevalence of $T$. gondii in beavers reported here is low compared to that in other surveys of aquatic wildlife in the United States. One study in North Carolina found that $45 \%$ of river otters sampled were seropositive for $T$. gondii using a latex agglutination test (Tocidlowski et al., 1997).

The infected beavers in the present study may be ingesting $T$. gondii oocysts excreted by wild or domestic cats from contaminated water or foliage. Bobcats are the only wild cats that live in Massachusetts, where they are most common in the central and western regions. Although to our knowledge no prevalence data exist for $T$. gondii in bobcats from Massachusetts, we are aware of studies conducted in other parts of the United States. Kikuchi et al. (2004) tested serum from 52 bobcats from various states for antibodies to $T$. gondii, and $50 \%$ of the animals were seropositive.

We are unaware of any previous reports of $S$. neurona infection in beavers. However, a recent study examined other wildlife species from Connecticut for agglutinating antibodies to $S$. neurona. Eleven of 24 skunks $(46 \%)$ and 12 of 12 raccoons $(100 \%)$ had positive titers to $S$. neurona (Mitchell et al., 2002). Another study found that 24 of 25 raccoons (96\%) from Massachusetts were seropositive for S. neurona (Lindsay et al., 2001). Compared to these and other studies, the prevalence of $S$. neurona infection in beavers observed in the present study is low.

Opossums are the definitive host for S. neurona, and they are abundant throughout Massachusetts. Prevalence data are not available for S. neurona infections in opossums from Massachusetts, but studies have been conducted in Maryland and Michigan. These studies found that 6 of 11 opossums (55\%) from Maryland (Dubey, 2000), and 31 of 206 opossums (15\%) from Michigan (Elsheikha et al., 2004), were infected with S. neurona.

The prevalence of $T$. gondii and $S$. neurona in beavers from Massachusetts is lower than what has been observed in other wildlife species. However, even a small number of infected animals indicates the presence of parasites in the area.

\section{LITERATURE CITED}

Deblinger, R. D., W. A. Woytek, AND R. R. Zwick. 1999. Demographics of voting on the 1996 Massachusetts ballot referendum. Human Dimensions of Wildlife 4: 40-55.

Dubey, J. P. 1994. Toxoplasmosis. Journal of the American Veterinary Medical Association 205: 1593-1598.

. 1998. Toxoplasma gondii oocyst survival under defined temperatures. Journal of Parasitology 84: 862-865.

. 2000. Prevalence of Sarcocystis species sporocysts in wildcaught opossums (Didelphis virginiana). Journal of Parasitology 86: $705-710$.

. 2004. Toxoplasmosis-A waterborne zoonosis. Veterinary Parasitology 126: 57-72.

, AND G. DESMONTS. 1987. Serological responses of equids fed Toxoplasma gondii oocysts. Equine Veterinary Journal 19: 337-339.

Elsheikha, H. M., A. J. Murphy, AND L. S. MANSField. 2004. Prevalence of Sarcocystis species sporocysts in Northern Virginia opossums (Didelphis virginiana). Parasitology Research 93: 427-431.

Frenkel, J. K., A. Ruiz, and M. Chinchilla. 1975. Soil survival of Toxoplasma oocysts in Kansas and Costa Rica. American Journal of Tropical Medicine and Hygiene 24: 439-443.

Hsu, H., G. F. Grady, J. H. Maguire, B. J. Weiblen, and R. Hoff. 1992. Newborn screening for congenital Toxoplasma infection: Five years experience in Massachusetts, USA. Scandinavian Journal of Infectious Disease 84: 59S-64S.

Kikuchi, Y., B. B. Chomel, R. W. Kasten, J. S. Martenson, P. K. SWIFT, AND S. J. O'Brien. 2004. Seroprevalence of Toxoplasma gondii in free-ranging or captive pumas (Felis concolor) and bobcats (Lynx rufus). Veterinary Parasitology 120: 1-9.

Koenen, K., S. DeStefano, C. Henner, and T. Beroldi. From the field: capturing beavers in box traps. Wildlife Society Bulletin (in press).

Lancia, R. A., R. P. Brooks, and M. W. Fleming. 1978. Ketamine hydrochloride as an immobilant and anesthetic for beavers. Journal of Wildlife Management 42: 946-948.

LindSAY, D. S., AND J. P. Dubey. 2001. Direct agglutination test for the detection of antibodies to Sarcocystis neurona in experimentally infected animals. Veterinary Parasitology 95: 179-186.

, A. C. Rosypal, J. A. Spencer, M. A. Cheadle, A. M., Zajac, C. Rupprecht, J. P., Dubey, and B. L. Blagburn. 2001. Prevalence of agglutinating antibodies to Sarcocystis neurona in raccoons, Procyon lotor, from the United States. Veterinary Parasitology 100: 131-134.

Mitchell, S. M., D. J. Richardson, M. A. Cheadle, A. M. Zajac, AND D. S. LinDSAY. 2002. Prevalence of agglutinating antibodies to Sarcocystis neurona in skunks (Mephitis mephitis), raccoons (Procyon lotor), and opossums (Didelphis virginiana) from Connecticut. Journal of Parasitology 88: 1027-1029.

Nogami, S., H. Kamata, S. Maruyama, H. Furuya, and I. Inoue. 1992. Preservation of feline anti-Toxoplasma gondii antibody activity using blood absorbed on filter paper stored under different conditions. Research in Veterinary Science 52: 387-388.

Patel, B., AND R. E. Holliman. 1994. Antibodies to Toxoplasma gondii in eluates from filter paper blood specimens. British Journal of Biomedical Science 51: 104-108.

PAtroneK, G. J. 1998. Free-roaming and feral cats-Their impact on wildlife and human beings. Journal of the American Veterinary Medical Association 212: 218-226.

Paul, M., E. Petersen, AND J. Szczapa. 2001. Prevalence of congenital Toxoplasma gondii infection among newborns from the Poznan region of Poland: Validation of a new combined enzyme immunoassay for Toxoplasma gondii-specific immunoglobulin A and immunoglobulin M antibodies. Journal of Clinical Microbiology 39: 1912-1916.

Smith, D. D., AND J. K. Frenkel. 1995. Prevalence of antibodies to Toxoplasma gondii in wild mammals of Missouri and east central Kansas: Biologic and ecologic considerations of transmission. Journal of Wildlife Diseases 31: 15-21.

Tocidlowski, M. E., M. R. LAPPin, P. W. SuMmer, AND M. K. Stoskopf. 1997. Serologic survey for toxoplasmosis in river otters. Journal of Wildlife Diseases 33: 649-652.

UgGLA, A., AND L. A. NiLSSON. 1987. Evaluation of a solid-phase immunoassay (DIG-ELISA) for the serodiagnosis of ovine toxoplasmosis. Veterinary Immunology and Immunopathology 14: 309-318. 